\title{
Synthesis and anti-depressant evaluation of novel pyrazolone derivatives
}

\section{Vijay Kumar Merugumolu and Revanasiddappa Bistuvalli Chandrashekarappa}

Department of Pharmaceutical Chemistry, NGSM Institute of Pharmaceutical Sciences of Nitte University, Paneer, Deralakatte, Mangalore 575-018, Karnataka, India.

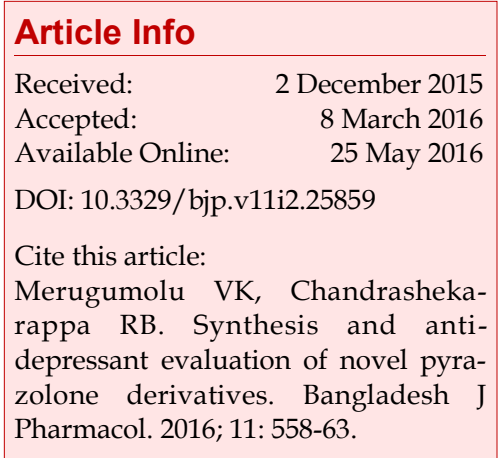

\begin{abstract}
Diazotization of substituted anilines with $\mathrm{NaNO}_{2}$ and concentrated hydrochloric acid at $0^{\circ} \mathrm{C}$ gave the diazonium chlorides. Coupling of substituted aryl diazonium chlorides with ethyl acetoacetate in methanol gave ethyl-2-arylhydrazono-3-oxobutyrates $(\mathbf{2 a}-\mathbf{h})$. Reaction of (2a-h) with naphthoic carbohydrazide (3) gave the title compounds pyrazolone derivatives (4a-h). The newly synthesized compounds were screened for their in vivo anti-depressant activity by tail suspension test and forced swimming test. Some of the tested compounds $\mathbf{4 f}, \mathbf{4 g}$ showed very good activity when compared to the standard drug imipramine. The newly synthesized compounds were characterized by physical parameters and the structures were elucidated by spectral data.
\end{abstract}

\section{Introduction}

Pyrazolone is a 5 membered lactam ring containing 2 nitrogen and a ketone in the same molecule or alternatively a derivative of pyrazole possessing additional ketone ring. Antipyrine (2,3-dimethyl-1-phenyl-3-pyrazolin-5-one) is the one of the earliest synthetic drugs introduced in 1884 for treating fever, pain and inflammation. Butazolidine, another pyrazolone, is a powerful anti-inflammatory drug used in rheumatic conditions. Some of the medicinal pyrazolone derivatives include ampyrone, metamizole and phenyl butazone.

Depression is one of the most commonly encountered neurological disorders. It is a common chronic recurrent syndrome, characterized by apathy and loss of energy (McNamara, 2011). Anti-depressants and anticonvulsants are among the most widely used drugs for the treatment of central nervous system (CNS) disorders (Mochizucki, 2004). Tricyclic anti-depressants (amitriptyline, nortriptyline, imipramine), norepinephrine dopamine reuptake inhibitors (bupropion, dexmethylphenidate), monoamine oxidase inhibitors (phenelzine, moclobemide), selective serotonin re-uptake inhibitors (paroxetine, fluoxetine, citalopram, escitalopram, fluvoxamine, sertraline), serotoninenorepinephrine re-uptake inhibitors (duloxetine and venlafaxine), $5-\mathrm{HT}_{2}$ receptor antagonists, norepinephrine reuptake inhibitors, are the major anti-depressant drug classes used for the treatment of depressive disorders (Anacker, 2014; Immadisetty et al., 2013; Artigas, 2013). Anti-depressants are used from the past decades, but suffer from so many adverse effects including fatigue, sleep disturbance sedation, cognitive impairment. Therefore, the need of development of new synthetic heterocyclics as new anti-depressant drugs with fewer adverse effects and possessing greater effectiveness is desirable (Wardhakan et al., 2008).

One of the recently invented drug, edaravone (3-methyl -1-phenyl-2-pyrazolin-5-one), has shown to produce marked attenuation of brain damage caused by ischemia-reperfusion (Anzai et al., 2004) and its pharmacological effects were mainly due to its anti-oxidant property, as a potent hydroxyl radical scavenger (Parmar et al., 1999).

Pyrazolone and its derivatives have attracted intense interest because of their potential applications as antibacterial (Desai and Desai, 2005), analgesic (Uramaru et 
al., 2010), antifungal (Singh and Singh, 1991), antitumor (Wang et al., 2010), anti-inflammatory (Mariappan et al., 2010), SARS-corona virus 3C-like protease inhibitors (Ramajayam et al., 2010) and anti-oxidant (Sivakumar and Rajasekharan, 2012). Owing to the above pharmacological activities exhibited by pyrazolones, it was contemplated to synthesize a novel series of pyrazolone derivatives and their subsequent in vivo anti-depressant activity. The newly synthesized pyrazolones were characterized by the spectral data.

\section{Materials and Methods}

Melting points were determined by open capillary method and were uncorrected. The IR spectra (in $\mathrm{KBr}$ pellets) were recorded on a Alpha Bruker FT-IR spectrophotometer. ${ }^{1} \mathrm{H}-\mathrm{NMR}$ spectra were recorded on a Bruker avance $300 \mathrm{MHz}$ NMR spectrometer, in DMSO $-\mathrm{d}_{6}$ using TMS as internal standard. Chemical shifts were recorded in parts per million down-field. The purity of the compounds was checked by thin layer chromatography on silica gel $60 \mathrm{~F}_{254}$ Merck plate using a mixture of ethyl acetate and methanol, as mobile phase. The mass spectrometry was recorded on LC-MS Shimadzu 2020 series in electrospray ionization mode. Elemental analysis (C, $\mathrm{H}$ and $\mathrm{N}$ ) was performed on Carlo Elba 1108 analyzer. The spots were visualized by exposure to iodine vapors. All other chemicals and solvents used were of commercial grade and used without purification and were procured from Alfa aesar, Spectrochem, Himedia, Sigma-Aldrich.

The key intermediate compounds ethyl-2-arylhydrazono-3-oxobutyrate (2a-h) were prepared as per the reported procedure (Revanasiddappa et al., 2013).

\section{Synthesis of substituted pyrazolones $(4 a-h)$}

Ethyl-2-arylhydrazono-3-oxobutyrate (2a-h) (0.01 mol/
L) and naphthoic carbohydrazide (3) (0.01 mol/L) was dissolved in glacial acetic acid $(20 \mathrm{~mL})$ and the reaction mixture was refluxed for about 24-34 hours. After cooling, the reaction content was poured into ice water mixture. The reaction mixture was stirred and the precipitated solid was collected by filtration, washed with water and recrystallized from ethanol. The physical data of compounds (4a-h) is given in Table I.

(Z)-1-(2-naphthoyl)-4-(2-(4-bromophenyl)hydrazono)-3methyl-1H-pyrazol-5(4H)-one (4a): IR $\left(\mathrm{V}_{\max } \mathrm{cm}^{-1}\right): 3194$ (NH), $3084(\mathrm{C}-\mathrm{H}), 1721(\mathrm{C}=\mathrm{O}), 1555(\mathrm{C}=\mathrm{N}), 1478$ $(\mathrm{C}=\mathrm{C}), 771$ (C-Br); ${ }^{1} \mathrm{H}$ NMR: (DMSO-d $\left.6, \delta, \mathrm{ppm}\right): 2.14(\mathrm{~s}$, $\left.\mathrm{CH}_{3}, 3 \mathrm{H}\right), 7.11-8.88$ (m, Ar-H, 11H), 11.60 (s, NH, 1H); LC-MS (m/z, \%): $435 \quad\left[\mathrm{M}^{+}\right] ;$Anal. Calcd for $\mathrm{C}_{21} \mathrm{H}_{15} \mathrm{BrN}_{4} \mathrm{O}_{2}$ : C, 57.95; $\mathrm{H}, 3.47, \mathrm{~N}, 12.87$. Found: $\mathrm{C}$, 57.98; H, 3.50, N, 12.90 .

(Z)-5-(4-(2-(1-(2-naphthoyl)-3-methyl-5-oxo-1H-pyrazol $-4(5 \mathrm{H})$-ylidene)hydrazinyl)phenyl)-N-phenylpyrimidine-2-sulfonamide (4b): IR $\left(\mathrm{v}_{\max } \mathrm{cm}^{-1}\right)$ : 3181 (NH), 3035 (C-H), $1717(\mathrm{C}=\mathrm{O}), 1576(\mathrm{C}=\mathrm{N}), 1485(\mathrm{C}=\mathrm{C}), 1340$ (SO $\mathrm{SO}_{2}$; ${ }^{1} \mathrm{H}$ NMR: (DMSO-d $\left.6, \delta, \mathrm{ppm}\right): 2.30\left(\mathrm{~s}, \mathrm{CH}_{3}, 3 \mathrm{H}\right)$, 7.05-8.88 (m, Ar-H, 18H), 11.64 (s, NH, 1H), 11.89 (s, $\left.\mathrm{SO}_{2} \mathrm{NH}, 1 \mathrm{H}\right)$; LC-MS (m/z, \%): $591[\mathrm{M}+1]$; Anal. Calcd for $\mathrm{C}_{31} \mathrm{H}_{23} \mathrm{~N}_{7} \mathrm{O}_{4} \mathrm{~S}$ : C, 63.15; $\mathrm{H}, 3.93, \mathrm{~N}, 16.63$. Found: $\mathrm{C}$, 63.19; H, 3.96, N, 16.67 .

(Z)-1-(2-naphthoyl)-3-methyl-4-(2-(4-nitrophenyl) hydrazono)-1H-pyrazol-5(4H)-one $(4 \mathrm{c})$ : IR $\left(\mathrm{v}_{\max } \mathrm{cm}^{-1}\right)$ : $3307(\mathrm{NH}), 3102$ (C-H), $1725(\mathrm{C}=\mathrm{O}), 1560(\mathrm{C}=\mathrm{N}), 1441$ $(\mathrm{C}=\mathrm{C})$; ${ }^{1} \mathrm{H}$ NMR: (DMSO-d $\left.6, \delta, \mathrm{ppm}\right): 2.20\left(\mathrm{~s}, \mathrm{CH}_{3}, 3 \mathrm{H}\right)$, 7.30-8.50 (m, Ar-H, 11H), 11.70 (s, NH, 1H); LC-MS (m/ z, \%): $400\left[\mathrm{M}^{+}\right]$; Anal. Calcd for $\mathrm{C}_{21} \mathrm{H}_{15} \mathrm{~N}_{5} \mathrm{O}_{4} ; \mathrm{C}, 62.84 ; \mathrm{H}$, 3.77, N, 17.45. Found: C, 62.88; H, 3.80, N,17.48.

(Z)-1-(2-naphthoyl)-4-(2-(4-fluorophenyl)hydrazono)-3-

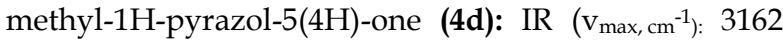
$(\mathrm{NH}), 3072(\mathrm{C}-\mathrm{H}), 1711(\mathrm{C}=\mathrm{O}), 1547(\mathrm{C}=\mathrm{N}), 1487$ $(\mathrm{C}=\mathrm{C}), 769$ (C-F); ${ }^{1} \mathrm{H}$ NMR: (DMSO-d $\left.6, \delta, \mathrm{ppm}\right): 2.36$ (s,

\begin{tabular}{|c|c|c|c|c|c|}
\hline \multicolumn{6}{|c|}{ Table I } \\
\hline \multicolumn{6}{|c|}{ Physical data of substituted pyrazolones (4a-h) } \\
\hline Compound & $\mathrm{R}-\mathrm{NH}_{2}$ & Molecular formula & Molecular weight & Melting point $\left({ }^{\circ} \mathrm{C}\right)$ & Yield (\%) \\
\hline $4 a$ & $4-\mathrm{Br}$ & $\mathrm{C}_{21} \mathrm{H}_{15} \mathrm{BrN}_{4} \mathrm{O}_{2}$ & 435 & $122-124$ & 60 \\
\hline $4 b$ & Sulfadiazine & $\mathrm{C}_{31} \mathrm{H}_{23} \mathrm{~N}_{7} 0_{4} \mathrm{~S}$ & 590 & $143-144$ & 62 \\
\hline $4 c$ & $4-\mathrm{NO}_{2}$ & $\mathrm{C}_{21} \mathrm{H}_{15} \mathrm{~N}_{5} 0_{4}$ & 401 & $101-103$ & 66 \\
\hline $4 d$ & $4-\mathrm{F}$ & $\mathrm{C}_{21} \mathrm{H}_{15} \mathrm{FN}_{4} \mathrm{O}_{2}$ & 374 & $111-113$ & 58 \\
\hline $4 \mathrm{e}$ & $4-\mathrm{Cl}$ & $\mathrm{C}_{21} \mathrm{H}_{15} \mathrm{ClN}_{4} \mathrm{O}_{2}$ & 391 & $172-174$ & 54 \\
\hline $4 \mathrm{f}$ & $3,4-\left(\mathrm{CH}_{3}\right)_{2}$ & $\mathrm{C}_{23} \mathrm{H}_{20} \mathrm{~N}_{4} \mathrm{O}_{2}$ & 384 & $158-160$ & 64 \\
\hline $4 g$ & $3,4-(\mathrm{Cl})_{2}$ & $\mathrm{C}_{21} \mathrm{H}_{14} \mathrm{Cl}_{2} \mathrm{~N}_{4} \mathrm{O}_{2}$ & 425 & $165-167$ & 56 \\
\hline $4 h$ & $2-\mathrm{CH}_{3}-3-\mathrm{Cl}$ & $\mathrm{C}_{22} \mathrm{H}_{17} \mathrm{ClN}_{4} \mathrm{O}_{2}$ & 405 & $96-98$ & 60 \\
\hline
\end{tabular}


$\left.\mathrm{CH}_{3}, 3 \mathrm{H}\right), 7.25-8.50 \quad(\mathrm{~m}, \mathrm{Ar}-\mathrm{H}, 11 \mathrm{H}), 8.88$ (s, NH, 1H); LC-MS (m/z, \%): $375[\mathrm{M}+1]$; Anal. Calcd for $\mathrm{C}_{21} \mathrm{H}_{15} \mathrm{FN}_{4} \mathrm{O}_{2} ; \mathrm{C}$, 67.37; H, 4.04, N, 14.97. Found: C, 67.41; $\mathrm{H}, 4.08, \mathrm{~N}, 14.94$.

(Z)-1-(2-naphthoyl)-4-(2-(4-chlorophenyl)hydrazono)-3-

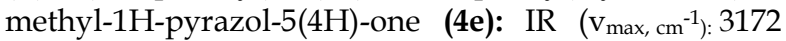
$(\mathrm{NH}), 3031(\mathrm{C}-\mathrm{H}), 1709(\mathrm{C}=\mathrm{O}), 1550(\mathrm{C}=\mathrm{N}), 1511(\mathrm{C}=\mathrm{C})$, 770 (C-Cl); ${ }^{1} \mathrm{H}$ NMR: (DMSO-d $\left.6, \delta, \mathrm{ppm}\right): 2.52\left(\mathrm{~s}, \mathrm{CH}_{3}\right.$, $3 \mathrm{H}), 7.27-8.88$ (m, Ar-H, 11H), 10.59 (s, NH, 1H); LC-MS (m/z, \%): $391[\mathrm{M}+1]$; Anal. Calcd for $\mathrm{C}_{21} \mathrm{H}_{15} \mathrm{ClN}_{4} \mathrm{O}_{2} ; \mathrm{C}$, 64.54; H,3.87, N, 14.34. Found: C, 64.58; H, 3.90, N, 14.37 .

(Z)-1-(2-naphthoyl)-4-(2-(2,4-dimethylphenyl) hydrazono)-3-methyl-1H-pyrazol-5(4H)-one (4f): IR $\left(\mathrm{v}_{\max } \mathrm{cm}^{-1}\right): 3153(\mathrm{NH}), 3045(\mathrm{C}-\mathrm{H}), 1765(\mathrm{C}=\mathrm{O}), 1550$ $(\mathrm{C}=\mathrm{N}), 1481(\mathrm{C}=\mathrm{C}) ;{ }^{1} \mathrm{H}$ NMR: $\left(\mathrm{DMSO}-\mathrm{d}_{6}, \delta, \mathrm{ppm}\right): 2.52$ (s, $\left.2 \times \mathrm{CH}_{3}, 6 \mathrm{H}\right), 7.11-8.88$ (m, Ar-H, 10H), 10.58 (s, NH, $1 \mathrm{H})$; LC-MS (m/z, \%): $385[\mathrm{M}+1]$; Anal. Calcd for $\mathrm{C}_{23} \mathrm{H}_{20} \mathrm{~N}_{4} \mathrm{O}_{2} ; \mathrm{C}, 71.86 ; \mathrm{H}, 5.24, \mathrm{~N}, 14.57$ Found: C, 71.83, $\mathrm{H}, 5.28, \mathrm{~N}, 14.60$.

(Z)-1-(2-naphthoyl)-4-(2-(2,4-dichlorophenyl) hydrazono)-3-methyl-1H-pyrazol-5(4H)-one (4g): IR $\left(\mathrm{V}_{\max } \mathrm{cm}^{-1}\right): 3232(\mathrm{NH}), 3077(\mathrm{C}-\mathrm{H}), 1718(\mathrm{C}=\mathrm{O}), 1559$ $(\mathrm{C}=\mathrm{N}), 1463(\mathrm{C}=\mathrm{C}), 771(\mathrm{C}-\mathrm{Cl})$; ${ }^{1} \mathrm{H}$ NMR: (DMSO-d ${ }_{6}$, S,ppm): 2.15 (s, $\left.\mathrm{CH}_{3}, 3 \mathrm{H}\right), 7.55-8.11$ (m, Ar-H, 10H), 10.59 (s, NH, 1H); LC-MS (m/z, \%): 425 [M+1]; Anal. Calcd for $\mathrm{C}_{21} \mathrm{H}_{14} \mathrm{Cl}_{2} \mathrm{~N}_{4} \mathrm{O}_{2}$ C, 59.31; H,3.32, N, 13.17 Found: C, 59.35, H, 3.36, N, 13.20.

(Z)-1-(2-naphthoyl)-4-(2-(2-chloro-3-methylphenyl) hydrazono)-3-methyl-1H-pyrazol-5 $(4 \mathrm{H})$-one (4h): IR

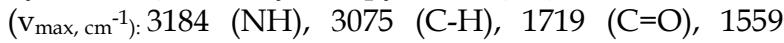
$(\mathrm{C}=\mathrm{N}), 1479$ (C=C), 773 (C-Cl); ${ }^{1} \mathrm{H}$ NMR: (DMSO-d $6, \delta$, ppm): 2.17 (s, $\left.\mathrm{CH}_{3}, 3 \mathrm{H}\right), 2.25\left(\mathrm{~s}, \mathrm{CH}_{3}, 3 \mathrm{H}\right), 7.45-8.50$ (m, Ar-H, 10H), 10.12 (s, NH, 1H); LC-MS (m/z, \%): 405 $[\mathrm{M}+]$; Anal. Calcd for $\mathrm{C}_{22} \mathrm{H}_{17} \mathrm{ClN}_{4} \mathrm{O}_{2} \mathrm{C}, 65.27 ; \mathrm{H}, 4.23, \mathrm{~N}$, 13.84 Found: $\mathrm{C}, 65.31 ; \mathrm{H}, 4.26, \mathrm{~N}, 13.88$.

\section{Animals}

Male Swiss albino mice (25-30 g) were used for screening of anti-depressant activity, of the newly synthesized compounds. All the animals were kept at $22 \pm 3^{\circ} \mathrm{C}$ and $65 \pm 55 \%$ relative humidity and during the whole experiment exposed to 12 hours light and dark cycle. Animals were given standard food pellet and water was supplied by ad libitum.

\section{Acute toxicity studies}

Acute toxicity studies (OECD, 2001) on Wister albino mice were carried out by standard method at oral of 100 $-1,000 \mathrm{mg} / \mathrm{kg}$ body weight as per OECD 425 guidelines. All the animals were continuously observed for 8 hours for any signs of acute toxicity such as ataxia, tremors, and convulsions. The acute toxicity studies revealed that all the compounds were found to be non-toxic up to $1,000 \mathrm{mg} / \mathrm{kg}$ body weight. The control group received 1\% Tween 80 suspension. Animals were kept in fasting condition prior to dosing.

\section{Forced swimming test (FST) (Video Clip)}

The newly synthesized compounds were screened for the anti-depressant activity using behavioral despair test (forced swimming test) (Porsolt et al., 1981). Imipramine $10 \mathrm{mg} / \mathrm{kg}$ as a reference anti-depressant drug was suspended in $1 \%$ aqueous solution of Tween 80 . On the testing day, mice were assigned into different groups ( $\mathrm{n}=6$ for each group). The synthesized compounds $(100 \mathrm{mg} / \mathrm{kg}$ ) were administered orally to mice at a volume of $0.5 \mathrm{~mL} /$ body weight. Control animals received $1 \%$ aqueous solution of Tween 80 . After one hour the mice were dropped at a time into flexi glass cylinder $(25 \mathrm{~cm}$ height $), 30 \mathrm{~cm}$ diameter containing water to a height of $20 \mathrm{~cm}$ at $21-23^{\circ} \mathrm{C}$ and left for $6 \mathrm{~min}$. At the end of first $2 \mathrm{~min}$, the animal showing initial vigorous struggling was considered as immobile. The duration of immobility was recorded during the last $4 \mathrm{~min}$ to total $6 \mathrm{~min}$ test (Table II).

\section{Tail suspension test (TST) (Video Clip)}

Tail suspension test (Dunham and Miya, 1957) is a behavior despair model of depression, employed in the anti-depressant activity by decreasing the immobility period produced by the various classes of anti-depressant drugs. Mice were suspended on the edge of the table $50 \mathrm{~cm}$ above the floor with the help of adhesive tape placed $1 \mathrm{~cm}$ from the tip of the tail, for a period of 6 min using stop watch and immobility period was recorded. Mice were considered immobile when it didn't show any body movement when they hanged passively and completely motionless. The decrease in immobility duration is considered as behavioral profile that indicates the anti-depressant like action (Table III).

\section{Statistical analysis}

The experimental data were expressed as mean \pm SEM. The data obtained were analyzed by ANOVA followed by Dunnet's test and used to evaluate the results by Graph pad prism software version 5.0. A p-value of less than 0.05 was considered statistically significant.

\section{Results}

\section{Chemistry}

The synthesized route to the target compounds is outlined in Scheme 1. Now we, hereby, reported the synthesis of novel pharmacologically active pyrazolone derivatives by the reaction of ethyl-2-arylhydrazono-3oxobutyrate (2a-h) and naphthoic carbohydrazide (3) in glacial acetic acid as solvent. The key intermediate compounds ethyl-2-arylhydrazono-3-oxobutyrate (2a-h) were prepared as per the reported procedure (Revanasiddappa et al., 2013). The purity of the compounds 


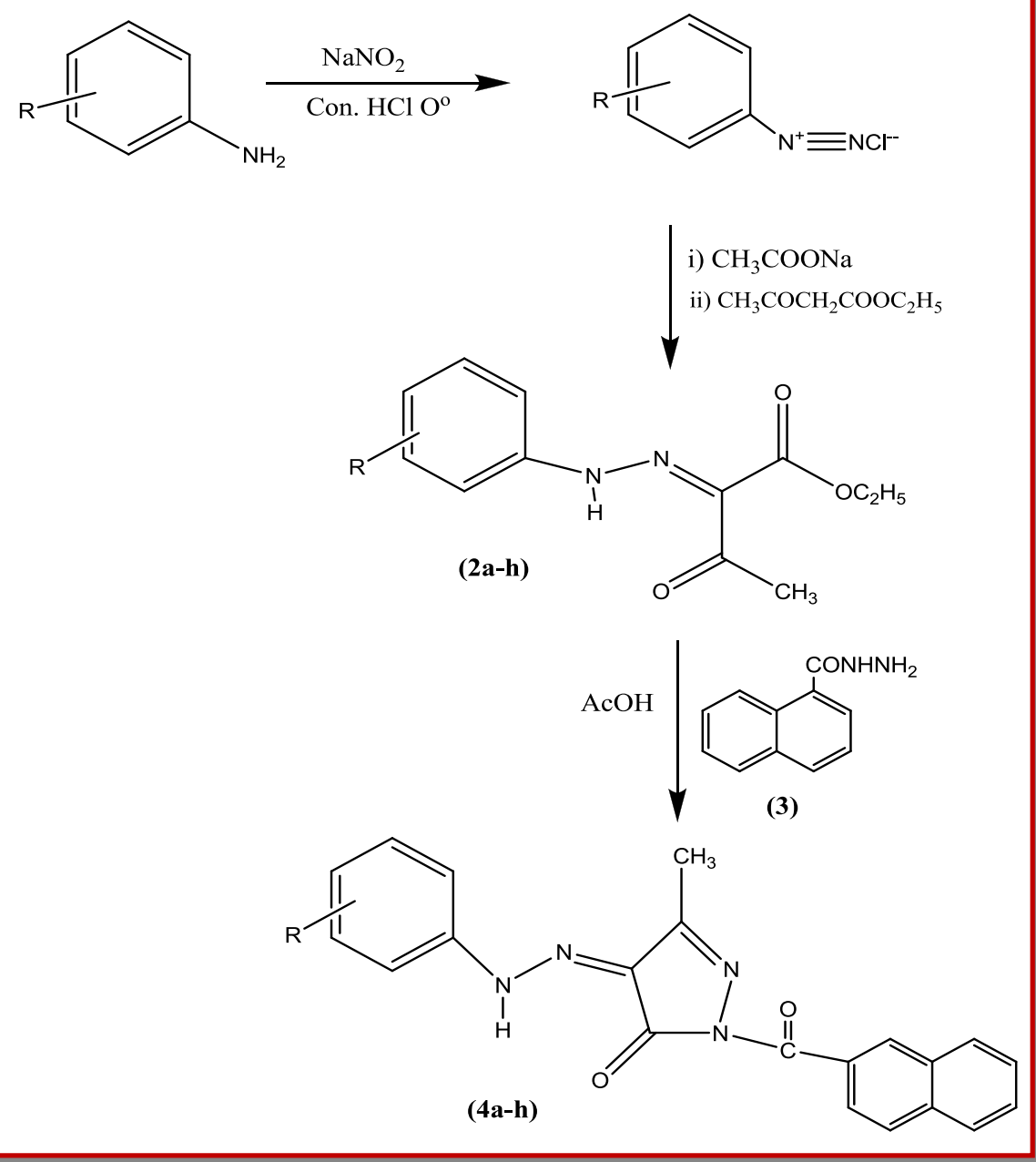

Scheme 1: Synthesized route to the target compounds

was established by recrystallization technique. The structures of the novel synthesized compounds were confirmed by spectral data (IR, ${ }^{1} \mathrm{H}-\mathrm{NMR}$, mass), which were in line with the proposed structure. The compounds were obtained in moderate to good yield.

IR spectra of compounds showed $\mathrm{NH}, \mathrm{C}=\mathrm{O}, \mathrm{C}=\mathrm{N}, \mathrm{C}=\mathrm{C}$ bands at 3307-3153 $\mathrm{cm}^{-1}, 1765-1709 \mathrm{~cm}^{-1}, 1576-1485 \mathrm{~cm}^{-1}$ regions respectively. In the $300 \mathrm{MHz}{ }^{1} \mathrm{H}-\mathrm{NMR}$ spectra of these compounds exhibited the expected characteristic signals for the aromatic protons near 7.30-8.50 ppm. The signals belonging to $\mathrm{NH}$ protons appeared as singlets at 11.89-8.88 ppm respectively, whereas the signals derived from pyrazolone methyl group were observed at 2.14-2.52 ppm as a singlet. Further evidence for the formation of pyrazolone was obtained by recording its mass spectrum. Mass spectra of the compound (4c) showed a $\left[\mathrm{M}^{+}\right]$peak, in line with their molecular formula. All the newly synthesized compounds were in conformity with the structures envisaged.

\section{Pharmacology}

The anti-depressant activity of the newly synthesized derivatives was carried out by FST and TST in mice at a dose of $100 \mathrm{mg} / \mathrm{kg}$ in comparison with imipramine 10 $\mathrm{mg} / \mathrm{kg}$. Anti-depressant activity was determined as mean immobility time in sec (Table II and III). The results revealed that some of the tested compounds (4f), (4g) have shown good activity in experimental animal models. In the series, naphthoic carbohydrazide based pyrazolone derivatives (4f), (4g) reduced immobility time in both FST and TST respectively at $100 \mathrm{mg} / \mathrm{kg}$ dose level when compared to imipramine.

The results revealed that the compounds (4f) possessing electron releasing group such as methyl substituents and compounds (4g) with electron withdrawing groups such as chlorine substituents on the aromatic rings considerably enhanced the anti-depressant activity. Compound (4c) with electron withdrawing group like nitro showed only moderate activity. The rest of the compounds showed very weak activity. The pharmacological data may be useful for further molecular modifications leading to compounds with greater favorable pharmacological properties. 
Table II

\begin{tabular}{|l|cc|}
\hline \multicolumn{3}{|c|}{$\begin{array}{c}\text { Anti-depressant activity of the title compounds by } \\
\text { forced swimming test method }\end{array}$} \\
\hline Compoundsa $^{\text {O }}$ & $\begin{array}{c}\text { Duration of immobility } \\
(\mathrm{s})\end{array}$ & $\begin{array}{c}\text { \% change in } \\
\text { immobility }\end{array}$ \\
\hline $4 \mathrm{~b}$ & $163.0 \pm 5.9$ & -19.8 \\
$4 \mathrm{c}$ & $141.5 \pm 3.6$ & -30.3 \\
$4 \mathrm{f}$ & $97.7 \pm 7.7$ & -51.9 \\
$4 \mathrm{~g}$ & $129.5 \pm 12.7$ & -36.3 \\
$4 \mathrm{~h}$ & $171.0 \pm 14.0$ & -15.8 \\
Control & $203.3 \pm 6.2$ & --- \\
Imipramine & $94.0 \pm 9.2$ & -53.8 \\
\hline
\end{tabular}

Values represent the mean $\pm \mathrm{SEM} ; \mathrm{n}=6$; aTested compounds and imipramine were tested at 100 and $10 \mathrm{mg} / \mathrm{kg}$ dose level, ip. respectively

\section{Table III}

Anti-depressant activity of the title compounds by tail suspension test method

Compoundsa $\quad$ Duration of immobility \%Change in

(s) immobility

\begin{tabular}{|c|c|c|}
\hline $4 b$ & $144.2 \pm 6.6$ & -22.3 \\
\hline $4 c$ & $119.3 \pm 9.4$ & -35.8 \\
\hline $4 \mathrm{f}$ & $114.3 \pm 8.0$ & -38.4 \\
\hline $4 g$ & $111.0 \pm 4.5$ & -40.2 \\
\hline $4 \mathrm{~h}$ & $147.3 \pm 5.1$ & -20.7 \\
\hline Control & $185.8 \pm 5.7$ & -- \\
\hline Imipramine & $109.0 \pm 6.9$ & -41.3 \\
\hline
\end{tabular}

Values represent the mean $\pm \mathrm{SEM} ; \mathrm{n}=6$; aTested compounds and imipramine were tested at 100 and $10 \mathrm{mg} / \mathrm{kg}$ dose level, ip. respectively

\section{Discussion}

Imipramine and the test compounds significantly shortened the immobility time of mice. The test compounds (Z)-1-(2-naphthoyl)-4-(2-(2,4-dimethylphenyl)hydrazono)-3-methyl-1H-pyrazol-5(4H)-one (4f), (Z)-1-(2naphthoyl)-4-(2-(2,4-dichlorophenyl)hydrazono)-3methyl-1H-pyrazol-5(4H)-one $(\mathbf{4 g})$ were found to be more effective when compared to imipramine and other derivatives showed weak activity.

It has been established that the shortening of immobility time in the forced swimming test and the suspension test depends mainly on the enhancement of central 5-HT and catecholamine neurotransmission. Early evidence of a role for noradrenaline in depression came from the discovery that drugs, either causing or alleviating depression. However, in the present study there is a decrease in immobility time detected and prolonged the swimming time without any change in the climbing time of mice, when compared with results of the control group. In TST, the tested compounds showed moderate activity. The experimental data obtained by both tests TST and FST exhibited that naphthoic carbohydrazide based pyrazolone derivative compounds have shown significant anti-depressant activities when compared to the standard drug imipramine. The results confirmed these findings for the tested compounds and provided information related to the possible mechanism of this activity. The results indicated the potency of the tested compounds (4f), (4g) in both FST and TST, showed a decrease in the immobility time.

The development of heterocyclic compounds such as pyrazoles and its derivatives as potent anti-depressants is very much progressing during the past few years (Ozdemir et al., 2007). In recent times pyrazoles and its derivatives emerged as promising scaffold for antidepressant activity (Mathew et al., 2013). MAO regulates the metabolic degradation of catecholamines, serotonin and other endogenous amines in central nervous system. Inhibition of this enzyme causes a reduction in metabolism and subsequent increase in the concentration of biogenic amines. The pyrazolone moiety might be interacting with adrenergic and serotonergic systems in mediating the anti-depressant effects. However, the precise mechanisms by which the compounds produced anti-depressant-like effect are not completely understood. Some of the test compounds showed remarkable attention in the inhibition of MAO$A$ and it is considered as the effective target for the management of depressive disorders (Prasad et al., 2005). Numerous studies have demonstrated that antidepressant drugs such as imipramine stimulated the action of serotonin and act by inhibiting the reuptake of biogenic amines in CNS. So in the present work a novel series of pyrazolones were synthesized and evaluated for anti-depressant activity with imipramine.

The results obtained from TST are in concordance with the validated FST. Some of the tested compounds showed good anti-depressant activity due to the presence of electron donating and electron withdrawing groups. The present experimental findings and the pharmacological evaluation suggests that pyrazolone derivatives are the promising anti-depressant agents. Imipramine prevents reuptake of nor adrenaline and serotonin resulting in their increased availability in the synapse and therefore an increase in adrenergic and serotonergic neuro-transmission. However, to establish the detailed mechanism of these compounds, further molecular interaction studies are necessary and have to be further carried out and also structural modification of the compounds in order to obtain potent and very less toxic compounds.

\section{Conclusion}

A novel series of pyrazolone derivatives were 
successfully synthesized and showed in vivo antidepressant activity.

\section{Conflict of Interest}

Authors declared no conflict of interest which is documented in the link present in HTML file.

\section{Ethical Issue}

All procedures involving animals were carried out as per OECD guidelines and animal treatment protocol was approved by Reg. No./115/1999/CPCSEA.

\section{Acknowledgement}

The authors are thankful to Nitte University, Mangalore for providing necessary facilities to carry out this research work. The authors are also thankful to Avra Laboratories Private Limited, Hyderabad for providing NMR and mass spectral data.

\section{References}

Anacker C. Fresh approaches to anti-depressant drug discovery. Expert Opin Drug Discov. 2014; 9: 407-21.

Anzai K, Furuse M, Yoshida A, Matsuyama A, Moritake T, Tsuboi K, Ikota N. In vivo radioprotection of mice by 3methyl-1-phenyl-2 pyrazolin- 5-one (edaravone; Radicut), a clinical drug. J Radiat Res (Tokyo). 2004; 45: 319-23.

Artigas F. Future directions for serotonin and anti-depressants. ACS Chem Neurosci. 2013; 4: 5-8.

Desai AR, Desai KR. Niementowski reaction: Microwave induced and conventional synthesis of quinazolinones and 3 -methyl-1H-5- pyrazolones and their antimicrobial activity. Arkivoc 2005; 8: 98-108.

Dunham NM, Miya TS. A note on simple apparatus for detecting neurological deficit in rats and mice. J Am Pharm. 1957; 46: 208-09.

Immadisetty K, Geffert LM, Surratt CK, Madura JD. New design strategies for anti-depressant drugs. Expert Opin Drug Discov. 2013; 8: 1399-414.

Mathew B, Suresh J, Anbazhagan S, Mathew GE. Pyrazoline: A promising scaffold for the inhibition of monoamine oxidase. Cent Nerv Syst Agents Med Chem. 2013; 13: 195-206.

Mariappan G, Saha BP, Satharson L, Haldar A. Synthesis and bioactivity evaluation of pyrazolone derivatives. Ind J Chem. 2010; 49B: 1671-74.
McNamara JO. Pharmacotherapy of the epilepsies. In: Goodman and Gilman's the Phamacological basis of therapeutics. Brunton LL, Chabner BA, Knollmann BC (eds.). 12 th ed. New York, McGraw-Hill, 2011, pp 583-608.

Mochizucki D. Serotonin and noradrenaline reuptake inhibitors in animal models of pain. Hum Psychopharmacol. 2004; 19: S15-19.

OECD. Acute oral toxicity: Up and down procedures, guidelines for testing of chemicals. No. 425. Paris, OECD, 2001.

Ozdemir Z, Kandilci HB, Gumusel B, Calis U, Bilgin AA. Synthesis and studies on anti-depressant and anti-convulsant activities of some 3-(2-furyl)-pyrazoline derivatives. Eur J Med Chem. 2007; 42: 373-79.

Parmar VS, Kumar A, Prasad AK, Singh SK, Kumar N, Mukherjee S, Raj GH, Goel S, Errington W, Puar MS. Synthesis of E- and Z pyrazolyl acrylonitriles and their evaluation as novel anti-oxidants. Bioorg Med Chem. 1999; 7: 1425-36.

Porsolt RD, Enna SJ, Malick JB, Richelson E, (eds). Antidepressants: Neurochemical, behavioral and clinical perspectives. New York, Raven Press, 1981, pp 121-39.

Prasad YR, Rao LA, Prasoona L, Murali Kumar RP. Synthesis and anti-depressant activity of some 1,3,5-triphenyl-2-pyrazolines and 3-(2"-hydroxy naphthalen-1"-yl)-1,5-diphenyl-2pyrazolines. Bioorg Med Chem Lett. 2005; 15: 5030-34.

Ramajayam R, Tan KP, Liu HG, Liang PH. Synthesis and evaluation of pyrazolone compounds as SARS-coronavirus 3C-like protease inhibitors. Bioorg Med Chem. 2010; 18: 7849-54.

Revanasiddappa BC, Thulasi N, Ansar M, Mahesh V, Anupama KP. Synthesis, antibacterial, anti-tubercular, antifungal, evaluation of some novel pyrazolone derivatives. Indian J Het Chem. 2013; 22: 373-76.

Singh D, Singh D. Synthesis and antifungal activity of some 4arylmethylene derivatives of substituted pyrazolones. J Indian Chem Soc. 1991; 68: 165- 67.

Sivakumar K, Rajasekharan A. Synthesis and Characterization, in vitro anti-oxidant activity of $\mathrm{N}$-mannich base of pyrazolone derivatives. Int J Res Pharm Chem. 2012; 2: 327-37.

Uramaru N, Shigematsu H, Toda A, Eyanagi R, Kitamura S, Ohta S. Design, synthesis and pharmacological activity of non allergenic pyrazolone type antipyretic analgesics. J Med Chem. 2010; 53: 8727-33.

Wang XH, Wang XK, Liang YJ, Shi Z, Zhang JY, Chen LM, Fu LW. A cell-based screen for anti-cancer activity of 13 pyrazolone derivatives. Chin J Cancer. 2010; 29: 980-87.

Wardhakan WW, Abdel-Salam OME, Elmegeed GA. Screening for anti-depressant, sedative and analgesic activities of novel fused thiophene derivatives. Acta Pharmacopoeia. 2008; 58: 1 -14 . 


\section{Your feedback about this paper}

1. Number of times you have read this paper 0

2. Number of times you have seen the video clip 0

3. Quality of paper
Excellent
$\bigcirc$ Good
Moderate
Not good

4. Your comments 